\title{
A pedagogia do fracasso
}

\section{Joana Almeida}

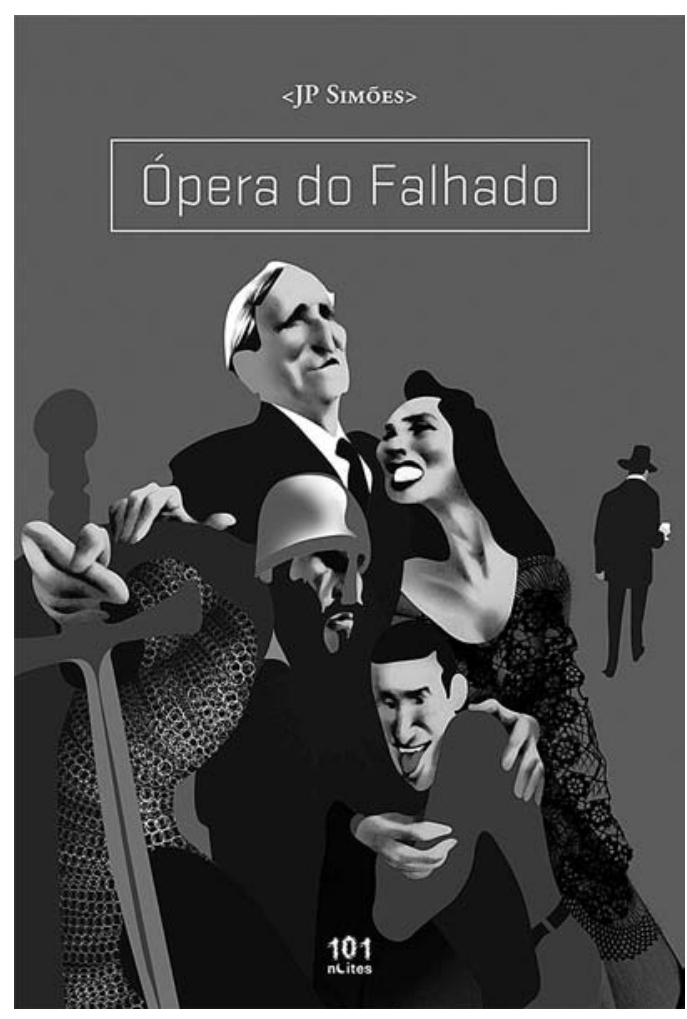

A Ópera do falhado oferece-nos uma comédia mordaz da cultura portuguesa, confrontando as aspirações megalómanas com a inércia que caracteriza a angústia de um indivíduo preso ao passado, mais interessado na lamúria do que em lutar pelos seus objectivos. Escrito por J. P. Simões e com prefácio de João Lourenço, o texto desta ópera dialoga com uma tradição de peso, onde devemos incluir, entre outras referências, The Beggar's Opera, de John Gay, a Ópera dos três vinténs, de Bertolt Brecht e Kurt Weill, e ainda a Ópera do malandro, de Chico Buarque.

0 texto esteve na origem de um espectáculo musical, estreado em Outubro de 2003, que nos desenhava a sociedade de um pais preso ao passado, talvez com aspirações futuras, mas vivendo um presente marcado pela apatia'. A sátira proposta pelo texto organiza-se em torno do reencontro de dois antigos colegas de liceu, após terem seguido rumos muito diversos. 0 autor serve-se assim de Ácaro e Ícaro, os protagonistas do enredo, para personificar simultaneamente o parasitismo e o espírito sonhador característicos na sociedade portuguesa. Ácaro e İcaro, parasita e sonhador respectivamente, encontram-se no velho café Inferninho da Baixa, que devido às suas memórias resiste a ser demolido. A decoração das paredes deste café expõe quadros representando alguns dos fantasmas do país, importantes

\author{
J. P. Simões, Ópera do falhado, Lisboa, \\ 101 Noites e J. P. Simões, 2004, 133 pp.
}

para o rumo da acção. Cada fantasma configura um arquétipo dos grandes símbolos de Portugal, como o Ditador, o Rei, a Fadista, o Poeta e o falecido filho dos proprietários do café.

0 Inferninho da Baixa representa a saudade, a memória e a evocação condensada do que já se perdeu, ou do que, mesmo em vida, não chegou a ser propriamente experimentado, apesar de nos aparecer como algo central na cultura portuguesa. Os donos do velho café, Afonso e Olga, vivem a frustração de não terem alcançado os seus desejos e deparam-se, através de Ácaro, com a possibilidade (duvidosa) de um futuro estável.

Henrique Céu de Aviz Castelo-Mayor-Que-0-Do-Outro de Ácaro é, segundo o próprio, Engenheiro Financeiro e representa a corrupção, a ambição, a desonestidade e o desrespeito pelas mulheres, já que uma das suas áreas de trabalho prende-se com a prostituição de meninas ucranianas. A sua vida está ligada a uma mulher sofredora, vítima de abusos na infância. Esta personagem retoma a conhecida noção do ensaio Labirinto da saudade, de Eduardo Lourenço, segundo a qual os portugueses são um povo de pobres com mentalidade de ricos. Nesta personagem, mais do que em qualquer outra, o parecer contradiz o ser. Ícaro representa o poeta falhado, embora seguro de que a inspiração há-de chegar um dia, a tempo de produzir uma "arte revolucionária e bela". Grande parte da acção foca o confronto entre Ácaro e Ícaro, conflito que resulta essencialmente do não reconhecimento de que ambos são simplesmente uns falhados.

Iniciado o declínio das diversas personagens, eis que os quadros ganham vida e deles saem os fantasmas, com soluções milagrosas para cada um dos problemas. Ao som da melodia "Grandessíssimas Expectativas", do Ditador, o que parece ser a salvação tão esperada, revela-se afinal uma reconstrução igualmente falhada do passado: "se, por exemplo, o povo vive na miséria, mas não gosta da mudança, a melhor coisa a fazer para lhe dar felicidade é reconstruir o passado. Dar-lhe uma história gloriosa para que, mesmo na miséria, tenha uma postura orgulhosa" (p. 113).

À boa maneira portuguesa, impera o regime do "tudo está bem quando acaba bem", ainda quando tal não passa de pura ficção. Seduzido pelas aparências, o povo acaba também por projectar o passado no futuro, raramente se fixa no presente.

0 texto de J. P. Simões procura responder a uma série de questões relacionadas com a identidade portuguesa. Enquanto conjunto de tradições, caracteres partilhados, estados e obrigações morais inquestionáveis, esta identidade
10 espectáculo teve estreia a 29 de Outubro de 2003, no Grande Auditório do Rivoli Teatro Municipal, com encenação de João Paulo Costa e produção da ACE - Academia Contemporânea do Espectáculo / Teatro do Bolhão. 
Cartaz da Ópera do

falhado,

de J.P. Simões, posiciona os indivíduos no mundo, justamente pela partilha imaginária de um sujeito colectivo a que se pertence. Esta identidade colectiva encontra no passado o seu fio condutor e a sua razão de (não) ser. 0 carácter nacional assenta exclusivamente na projecção obsessiva do passado. Isto mesmo se confirma através da aparição dos fantasmas, emanação quase transcendental de uma história, de uma cultura e de uma política. 0 país desta ópera não se encontra no seu melhor. Os problemas na saúde, na educação e na economia tornam o ser lusitano algo amargurado e descontente, embora persista sonhador, à custa de um halo do passado que teima em não morrer como passado.

0 fado é a música que melhor espelha o cinzentismo emocional da nação. As pessoas levam tudo demasiado a sério, como se cada gesto quotidiano constituisse uma afronta perante o peso esmagador do passado. Dai que a ousadia dos artistas justifique a sua marginalização: os artistas não levam a vida a sério. Por outro lado, o povo desta ópera não tem capacidade de indignação e limitase a viver com a sensação de que o destino é culpado por todo o mal que possa acontecer. Este fatalismo, tão caracteristicamente português, justifica o sarcasmo do autor, ao qualificar os habitantes da Lusitânia como uma raça de pessimistas insaciáveis, sonhadores eternos que jamais atingem os seus objectivos.

Inexplicavelmente, a imaginação dos portugueses aparenta um optimismo conformado. 0 final feliz deste enredo deve-se às palavras ilusórias do Ditador que em tempos foi o representante máximo da nossa nação. Num acto de pura magia, o Ditador transforma o passado das amarguradas personagens em contos de fadas. 0 conformismo revela-se em toda a sua profundidade nestas personagens que confiam num chefe político já morto. 0 povo gosta do modelo paternal do Ditador, o chefe que convence pela abnegação dedicada, uma atitude muito admirada pela mediocridade nacional.

A Ópera do falhado é um retrato em clave paródica dos habitantes deste pequeno país. Mas o retrato não ficaria completo sem o "monstro" da saudade, o suprasumo da mitologia nacional, o nosso impeto para a recordação nostálgica e paralisante. 0 mito do Sebastianismo surge então com toda a naturalidade. Não por acaso, um dos fantasmas do Inferninho da Baixa é um Rei. Apesar de todo o tempo que nos separa de D. Sebastião, o povo falhado anseia pelo seu retorno na pele de um herói, pronto para o exercício de salvação nacional. 0 mito sebastianista contém uma promessa redentora, bem necessária ao real falhado das personagens. Enquanto mito, D. Sebastião favorece a encenação heróica, permite a criação de figuras que o povo se encarrega de amplificar, juntamente com alguns escritores, como foi perversamente o caso de J. P. Simões. A introdução de alguns fantasmas na Ópera do

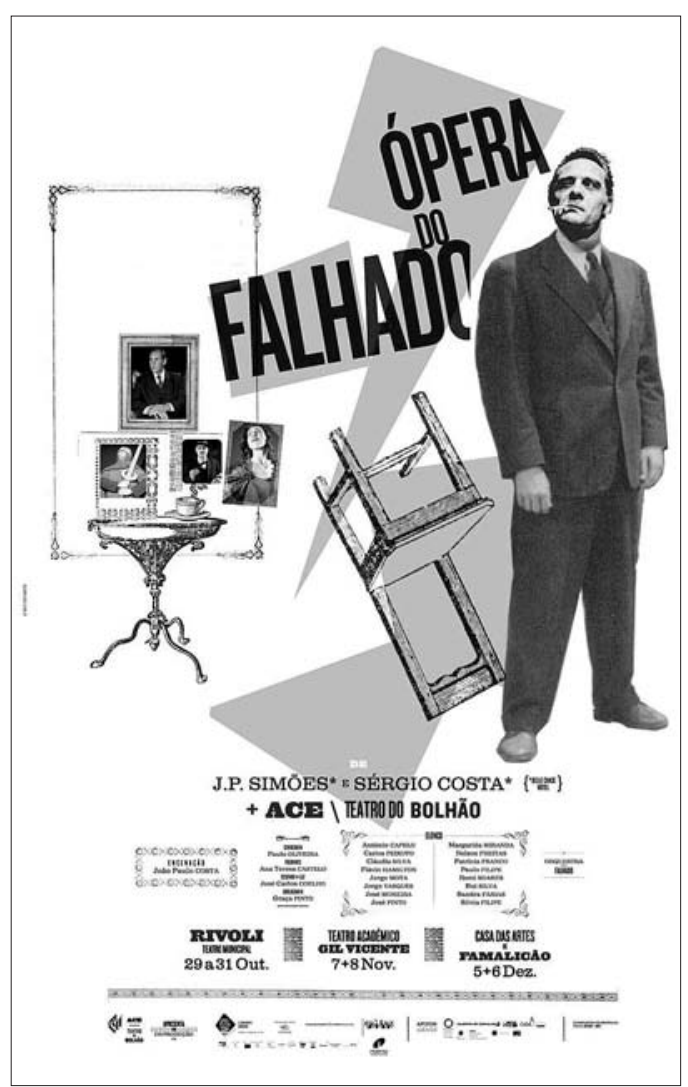

falhado torna-se importante para viabilizar a provocação final, enunciando um fim (aparentemente) feliz para as personagens.

A leitura do texto não deixa de nos representar de uma ou de outra forma. Trata-se de uma sensação estranha, justamente pelo falhanço que desde o título paira sobre as personagens. Não seremos todos um pouco falhados? Servirá a consumação do falhanço para justificar a inércia fundamental da "raça" lusitana? 0 leitor poderá buscar resposta parcial a estas perguntas no texto de J. P. Simões, dando por certo que a ópera não regressará aos palcos nacionais. 0 leitor encontrará ainda neste texto uma crítica em versão trágico-cómica, revelando o falhanço como parte da matriz identitária do povo sereno e dócil da Lusitânia. Seremos um povo de falhados! A ópera apenas nos concede uma oportunidade para ensaiarmos um salto irónico para o exterior de tal amargura:

"Quem somos? Como sonhos entre sonhos, entre fábulas astrais e a canção dos animais mal escondidos, imorais. Hoje é dia de poesia, sobe o pano, luzes brilham, acabou-se a dor."

(Canção dos animais, p. 97) 